\title{
Efficacy of some biocides against Potato Leafhopper, Empoasca fabae (Homoptera: Cicadellidae), on cowpea
}

\author{
Nihad Aziz Khamas**, Hussein Ali Salim*, Hussein Ali Mutney** and Ferial Bahgat Hormoz ${ }^{\star * *}$ \\ * Directorate of Diyala Agriculture, ${ }^{* \star *}$ Collage of Agriculture, University of Diyala, ${ }^{* \star *}$ Collage of Agriculture, \\ University of Baghdad \\ h_salim11111@yahoo.com
}

\begin{abstract}
A field study was carried out in Khan Bani Saad district, Diyala province on 2015 to evaluate bio pesticides viz. Spinosad (Saccharopolyspora spinosa) , BSA3 (Beauveria bassiana), Mycotal (Lecanecillium muscarium) and using chemical insecticide Hatchi hatchi 15\% EC against Potato Leafhopper Empoasca fabae on cowpea. the rate of nymphs and adults population was significantly reduced in treatments Hatchi hatchi $(1.8,3.7)$, Mycotal $(3.3,4.7)$ , Spinosad $(3.3,5.6)$ and BSA3 $(3.7,6.4)$ compared with control $(6.4,9.2)$ respectively. The results was showed that superiority of Spinosad treatment in mortality of nymphs of $E$. fabae to (44.76\%) with significant differences from other treatments followed by mycotal (41.31\%), and then BSA3, which amounts to (29.77\%). Mycotal was showed high mortality in the adults of $E$. fabae to $50.6 \%$ then Spinosad (39.49\%) and BSA3 (30.15\%). This study shows that the use of one of these biocides in the field may be sufficient to reduce the numbers of nymphs and adults during the study season.
\end{abstract}

Keywords: Spinosad (Saccharopolyspora spinosa), BSA3 (Beauveria bassiana), Mycotal (Lecanecillium muscarium) and Empoasca fabae

\section{Introduction}

Cowpea (Vigna unguiculate L. Walp.) is one of the main grain legumes with high protein content. It is cultivated in tropical and subtropical regions and widely distributed throughout the world, The seeds are most often consumed, it is also used as a fodder [1;2] . The potato leafhopper, Empoasca fabae (Harris) (Hemiptera: Cicadellidae), is a sap-feeding insect that attacks a variety of plants including potato, alfalfa and soybean, [3]. The first record of $E$. fabae date back to 1841 when it was detected in Massachusetts, USA as a pest on Vicia faba L [4]. The feeding by the potato leafhopper causes a condition known as "hopper burn", Injury results in a yellowing at the tip of the leaves, in a V-shaped pattern. Both adults and nymphs are injurious, but nymphs can reduce yields more than twice as much as an equal number of adults. Toxins in the saliva of potato leafhopper induce swelling of cells [5]. Using synthetic chemicals as insect pest control has given rise to a number of problems, including adverse effects on the environment and human health [6]. Biological control agents are considered as alternatives to the synthetic pesticides due to their perceived increased level of safety and minimal environmental impacts $[7 ; 8]$. B. bassiana is the most widely used entomopathogenic fungi and have been used for biological control of agricultural pests [9]. Lecanicillium muscarium (previously known as verticillium lecanii) is a well-known pathogen of arthropods, it is a very common fungus attacking different insects and capable of infecting a wide range of insects [10]. Spinosad is a mixture of spinosyn A and spinosyn $\mathrm{D}$ and it's a secondary metabolite produces by the fermentation from the bacterium, Saccharopolyspora spinosa. This product is active against caterpillars, leaf miners, trips, Colorado potato beetle and some borers [11]. The objective of this study was to evaluate the efficacy of the microbial pesticide BSA3 (Beauveria bassiana), mycotal (Lecanicillium muscarium) and Spinosad (Saccharopolyspora spinosa) against Potato Leafhopper Empoasca fabae on cowpea .

\section{Materials and Methods}

The study was conducted in the Khan Bani Saad region, Diyala province, Iraq during 25/4/2015. 


\section{Collection of biocides}

BSA3 (Beauveria bassiana) was obtained from the National Center for Organic Agriculture - Ministry of Agriculture, which was loaded on millet seeds and used at a rate of $4 \mathrm{~g} /$ liter of water, the millet seeds were soaked in water for one hour then separated from the suspension by muslin cloth and number of spores was calculated in the Hemacytometer which was $1 \times 10^{8}$ spores / mL, then added a drop of material (Tween -20) concentration 0.01 to the fungus suspension, which helps to spread spores in the suspension [12]. Mycotal (Lecanicillium muscariium) produced by Koppert company (Netherlands) and used $4 \mathrm{~g} / \mathrm{L}$ to obtain concentration $1 \times 10^{7}$ spore / $\mathrm{ml}$ according to recommendations of this company. Spinosad (Saccharopolyspora spinosa) produced by Dow Agro Sciences company and used at rate $0.25 \mathrm{ml} /$ liter according to the recommendations. Chemical pesticide Hatchi hatchi $15 \%$ EC, active ingredient (Tolfenpyrad) produced by Nihon Nohyaku of Japan at a concentration of $20 \mathrm{ml} / \mathrm{L}$ as recommended by the company. treatment of control was sprayed with water only.

\section{Field experiment}

seeds of cowpea were sown after preparing and plowing of the field with area 2 acre on lines with length $12 \mathrm{~m}$, the distance between lines and plants were $2 \mathrm{~m}$ and $40 \mathrm{~cm}$ respectively, the seedlings were spraying with microbial pesticides after ten days from the emergences. The leaf hopper population (nymphs and adults) were recorded from each treatment early in the morning during the period of growth of the crop until harvest for the period from 18/5/2015 to 20/6/2015 after 2,5,10,14,21 and 30 day from the spraying, three plants were selected from each replicate for insect population counts taking 3 leaves from each plant and put in bags of polyethylene then transferred to the laboratory for examined by a magnifying glass or used light microscope when needed after placing the samples in the refrigerator for 1-2 hours to inhibit the movement of insects. The insect population reduction percentage was computed through Abbott formula [13].

$\mathrm{n}$ in $\mathrm{T}$ after treatment

Corrected $\%=(1-$ $\times 100$

$\mathrm{n}$ in Co after treatment

Where $: \mathrm{n}=$ Insect population, $\mathrm{T}=$ treated, $\mathrm{Co}=$ control

\section{Statistical analysis}

The factorial experiment was carried out according to the complete randomized blocks design (RCBD) in the field include five treatments with three replications and the results were compared using the least significant difference of (L.S.D) below the level of probability 0.05 and the program [14]. SAS/STAT. User's Guide for personal computers. Release6.12 SAS Institute Inc., Cary . NC, U.S.A.

was used to analyze the statistical data.

\section{Results and discussion}

Table 1 illustrated that all treatments were recorded reduction in population of nymphs as compared with control. S. spinosa was recorded higher reduction in population of nymphs 1.5 after 5 and 14 days of spraying whereas B. bassiana 2.0 after 10 days while L.muscariium was superior in reduction of nymphs population to 6.0 and 1.3 after 21 and 30 days from spraying, the rate of population was significantly reduced in treatments Hatchi hatchi 1.8, L. muscariium 3.3 , S. spinosa 3.5and B. bassiana 3.7 as compared with control 6.4. 
Table (1): Numbers of nymphs of potato leafhopper E. fabae before and after spraying

\begin{tabular}{|l|l|l|l|l|l|l|l|l|}
\hline \multirow{2}{*}{ Treatments } & \multirow{2}{*}{$\begin{array}{l}\text { Numbers of nymphs } \\
\text { before spraying }\end{array}$} & \multicolumn{6}{|l|}{ Numbers of nymphs after spraying } \\
\cline { 3 - 9 } & & \multicolumn{3}{|l|}{ Days } \\
\cline { 3 - 9 } & & $\mathbf{2}$ & $\mathbf{5}$ & $\mathbf{1 0}$ & $\mathbf{1 4}$ & $\mathbf{2 1}$ & $\mathbf{3 0}$ & \multirow{2}{*}{ Rate } \\
\hline B. bassiana & 2.2 & 4.0 & 2.3 & 2.0 & 2.3 & 9.5 & 2.5 & 3.7 \\
\hline L.muscariium & 2.2 & 4.0 & 2.4 & 3.0 & 3.5 & 6.0 & 1.3 & 3.3 \\
\hline S. spinosa & 3.7 & 4.0 & 1.5 & 3.0 & 1.5 & 9.5 & 1.5 & 3.5 \\
\hline Hatchi hatchi & 1.5 & 0.9 & 1.0 & 1.0 & 3.2 & 3.2 & 1.2 & 1.8 \\
\hline Control & 4.0 & 4.2 & 5.3 & 5.0 & 10.0 & 11.5 & 2.5 & 6.4 \\
\hline L.S.D 0.05 & $\mathbf{1 . 4}$ & $\mathbf{1 . 4}$ & $\mathbf{2 . 1}$ & $\mathbf{2 . 8}$ & $\mathbf{2 . 8}$ & $\mathbf{0 . 7}$ & $\mathbf{1 . 4}$ & $\mathbf{0 . 5}$ \\
\hline
\end{tabular}

L. muscariium was found effective in reducing the population of adults with significant differences from other treatments after 10,21 and 30 days from spraying and also rate of adults numbers which reached 3.3,3.5,2.5 and 4.7 respectively (Table 2 ).

Table (2): Numbers of adults of potato leafhopper $E$. fabae before and after spraying

\begin{tabular}{|l|l|l|l|l|l|l|l|l|}
\hline \multirow{2}{*}{ Treatments } & \multirow{2}{*}{$\begin{array}{l}\text { Numbers of adults } \\
\text { before spraying }\end{array}$} & \multicolumn{6}{|l|}{ Numbers of adults after spraying } \\
\cline { 3 - 9 } & & \multicolumn{3}{|l|}{ Days } \\
\cline { 3 - 9 } & & $\mathbf{2}$ & $\mathbf{5}$ & $\mathbf{1 0}$ & $\mathbf{1 4}$ & $\mathbf{2 1}$ & $\mathbf{3 0}$ & \\
\hline B. bassiana & 3.0 & 8.2 & 6.0 & 6.2 & 6.7 & 8.2 & 3.5 & 6.4 \\
\hline L.muscariium & 3.0 & 8.2 & 6.0 & 3.3 & 5.0 & 3.5 & 2.5 & 4.7 \\
\hline S. spinosa & 3.0 & 8.2 & 6.0 & 4.9 & 5.0 & 6.0 & 3.5 & 5.6 \\
\hline Hatchi hatchi & 4.0 & 3.0 & 3.5 & 5.5 & 3.0 & 4.0 & 3.5 & 3.7 \\
\hline Control & 3.0 & 13.0 & 10.0 & 10.0 & 8.0 & 8.0 & 6.2 & 9.2 \\
\hline L.S.D 0.05 & $\mathbf{1 . 6}$ & $\mathbf{2 . 2}$ & $\mathbf{2 . 3}$ & $\mathbf{1 . 5}$ & $\mathbf{2 . 1}$ & $\mathbf{1 . 6}$ & $\mathbf{1 . 7}$ & $\mathbf{0 . 8 3}$ \\
\hline
\end{tabular}

All treatments after the spraying were significantly different in mortality of nymphs of leaf hopper, Hatchi hatchi was recorded higher corrected percentage at all intervals after spraying, whereas S. spinosa , B. bassiana and $L$. muscariium were recorded higher corrected percentage with significantly differences after 14 days which was $90.0,77.0,67.0 \%$ respectively, while the statically analysis revealed significant differences in rate of corrected efficacy percentage of nymphs among treatments viz Hatchi hatchi $72.4 \%$ followed by S. spinosa 44.7 \%, L. muscariium $41.3 \%$ and B. bassiana $29.7 \%$ (Table 3) . 
Table. 3 Efficacy of some biocides and chemical pesticide against nymphs of potato leafhopper E. fabae on cowpea plants

\begin{tabular}{|c|c|c|c|c|c|c|c|}
\hline \multirow[b]{2}{*}{ Treatments } & \multicolumn{6}{|l|}{ Days } & \multirow[b]{2}{*}{ Rate } \\
\hline & 2 & 5 & 10 & 14 & 21 & 30 & \\
\hline B. bassiana & 0.0 & 56.6 & 60.0 & 77.0 & 15.0 & 0.0 & 29.7 \\
\hline L.muscariium & 0.0 & 50.9 & 40.0 & 67.0 & 46.9 & 50.0 & 41.3 \\
\hline S. spinosa & 6.9 & 75.4 & 40.0 & 90.0 & 17.7 & 38.4 & 44.7 \\
\hline Hatchi hatchi & 86.0 & 81.1 & 80.0 & 67.0 & 70.8 & 50.0 & 72.4 \\
\hline L.S.D 0.05 & 2.5 & 5.3 & 6.4 & 3.04 & 2.8 & 5.0 & 2.0 \\
\hline
\end{tabular}

Data presented in Table 4 revealed that all treatments were recorded significantly different in corrected percentage of adults of leaf hopper at all intervals after spraying, Hatchi hatchi was recorded higher corrected percentage reached $76.9,67.0$ and $63.8 \%$ at 2,5 and 14 days respectively, L. muscariium was recorded highest significantly different in corrected percentage reached 67.0,60.2 and 63.4 at 10,21 and 30 days respectively followed by S. spinosa and B. bassiana .

Table 4: Efficacy of some biocides and chemical pesticide against adults of potato leafhopper $E$. fabae on cowpea plants

\begin{tabular}{|c|c|c|c|c|c|c|c|}
\hline \multirow[b]{2}{*}{ Treatments } & \multicolumn{6}{|l|}{ Days } & \multirow[b]{2}{*}{ Rate } \\
\hline & 2 & 5 & 10 & 14 & 21 & 30 & \\
\hline B. bassiana & 36.1 & 40.0 & 37.0 & 20.4 & 0.0 & 47.6 & 30.1 \\
\hline L.muscariium & 36.1 & 37.0 & 67.0 & 39.7 & 60.2 & 63.4 & 50.6 \\
\hline S. spinosa & 33.8 & 34.0 & 54.0 & 39.7 & 27.7 & 47.6 & 39.4 \\
\hline Hatchi hatchi & 76.9 & 67.0 & 44.0 & 63.8 & 51.8 & 42.8 & 57.7 \\
\hline L.S.D 0.05 & 3.2 & 4.3 & 2.8 & 3.4 & 3.2 & 4.1 & 3.0 \\
\hline
\end{tabular}

The previous studies were confirmed that spinosad remains active and performed well and has strong insecticidal activity against Lepidoptera, Spodoptera, Diptera, and some Coleoptera as well as stored grains [15]. S. spinosa (Spinosad 45 SC) was very effective against the sucking pests such aphids on ladysfinger [16]. Spinosad is introduced in the IPM due his action [17]. Spinosad is affecting on nerve receptors, including the G-amino butyric acid (GABA), which is similar to the toxic effect of chemical pesticides from the neonicotinoid group [18]. The results are agreed with [19] that reported the number of whitefly larvae was decreased with increasing concentrations of $L$. muscarium, the use of $L$. muscarium for integrated pest management of the whitefly Bemisia tabaci was successful to control this pest. Pathogencity of $L$. muscarium involves adhesion of spores to the insect cuticle, germination, penetration and internal colonization culminating in host death [20]. The findings are similar to [21] who reported that the maximum daily mortality (13.3\%) caused by Beauveria 
bassiana was observed on day 8 against Uvarovistia zebra. Application of B. bassiana was killed $100 \%$ of $B$. tabaci adults [22]. B. bassiana was found effective in reducing the population of whitefly in tomato crops [23].

\section{Conclusions}

The results revealed the efficacy of all biocides against potato leafhopper $E$. fabae on cowpea plants. Spinosad presented a quick action and a high mortality followed by L. muscariium and B. bassiana .we conclude that biocides can be incorporated in IPM programme and organic agriculture in the future.

\section{Conflict of Interest:}

The authors declare that they have no competing interests.

\section{Acknowledgements:}

Authors wish to thank Ministry of Agriculture, Directorate of Diyala Agriculture for awarding the opportunity to accomplish this work.

\section{References}

[1] Pasquet R.S. and Baudoin J.P., 2001. Cowpea. In: Charrier A., Jacquot M., Hamon S. and Nicolas D. (eds), Tropical Plant Breeding. Science publishers, Enfield, pp. 177-198.

[2] Fery, R. L.; Singh, B. B. ,1997. Cowpea genetics: a review of the recent literature. In: SINGH, B. B. et al. (Ed.) Advances in cowpea research. Ibadan: IITA: JIRCAS,. cap. 2, p. 13-15.

[3] Lamp, W. O., G. R. Nielsen, and S. D. Danielson., 1994. Patterns among host plants of the potato leafhopper, Empoasca fabae (Homoptera: Cicadellidae). J. Kans. Entomol. Soc. 67: 354Đ368.

[4] Harris, T. W. 1841. A report on the insects of Massachusetts, injurious to vegetation. Folsom, Wells, and Thurston, Printers to the University, Cambridge, MA.

[5] Trivedi , T.P. , Rajagopal , D. , 1999 . Integrated Pest Management in Potato . In: Upadhayay, R.K. , Mukeriji, K.G. , Dubey, O.P. (Eds.), IPM System in Agriculture, Cash Crops, Vol. 6 , Aditya Books Pvt. Ltd. , New Delhi, India, pp. $299-313$.

[6] Anonymous 2004. Green pesticides in insect pest management. A report on the National Symposium on Green Pesticides for Insect Pest Manegement, Entomological Research Institute, Chennai. Current Science. 86(8): 1059- 1060.

[7] Cotxarrera, L., M.I. Trillas-Gay, C. Steinberg and C. Alabouvette, 2002. Use of sewage sludge compost and Trichoderma asperellum isolates to suppress Fusarium wilt of tomato. Soil Biology and Biochemistry, 34: 467-476.

[8] Brimner, T.A. and G.J. Boland, 2003. A review of the non-target effect of fungi used to biologically control plant diseases. Agriculture, Ecosystem and environment100. 3-16.

[9] Shah PA, Kooyman C, Paraiso A. 1997. Surveys for fungal pathogens of locusts and grasshoppers in Africa and the Near East. Mem Entomol Soc Can 171: 27-35.

[10]Parker BL, Skinner M,Costa SD, Gouli S, Ried W, El-Bouhsini M, 2003. Entomopathogenic fungi Eurygaster integriceps Puton (Hemiptera: Scautelleridae):collection and characterization for development. Biological Control.; 27: 260:272. 
[11] Elzen, G.W.; Elzen, P.J. and King, E.G., 1998. Laboratory toxicity of insecticide residues to Orius insidiosus, Geocoris punctipes, Hippoclamia convergens and Chyrosoperla carnea. Southw. Entomol., 23: 335-342.

[12] Amiri, Salam Abbas 2009. Determination of the sources of heterogeneity of some isolates of Beauveria bassiana (Bals.) Vuill. and its efficiency against Sesamia cretica Led. (Lep .: Noctuida) under field conditions, doctoral thesis. Baghdad University . faculty of Agriculture .

[13] Abbott, W. S. 1925. A method of computing the effectiveness of an insecticide . Jou. Econ. Entomol. ; 18 : $265-267$.

[14] SAS , 2001. SAS/STAT. User's Guide for personal computers. Release6.12 SAS Institute Inc., Cary . NC, U.S.A.

[15] Mohamed Braham and Lobna Hajji, 2012. Management of Tuta absoluta (Lepidoptera, Gelechiidae) with Insecticides on Tomatoes, Insecticides - Pest Engineering, 334-354.

[16] Ghosh SK, Mahapatra GSS, Chakraborty G ,2009. Field efficacy of plant extracts and microbial insecticides against aphid (Aphis gossypii) infesting okra (Abelmoschus esculentus). Redia, Itali, XC11: 249-252.

[17] Thompson G.D., Michel K.H., Zao R.C., Mynderse J.S., Mosburg C.T., Worden T.V., Chio E.H., Sparks T.C., Hutchins S.H., 1997. The discovery of Saccharopolyspora spinosa and a new class of insect control product. Down to earth, vol. 52, nr. 1, p. 1-5.

[18] Salgado, V. 1998. Studies on the mode of action of spinosad: insect symptoms and physiological correlates. Pestic. Biochem. Physiol. ; 60:91-102

[19] Ren S.X., S. Ali, Z. Huang and J.H. Wu ,2010. Lecanicillium muscarium as microbial insecticide against whitefly and its interaction with other natural enemies, current research, technology and education topics in applied microbiology and microbial biotechnology,339-348.

[20] Gindin G, Barash NI, Raccah B., 1994.Effect of endotoxic compounds isolates from Verticillium lecanii on the sweet potato whitefly, Bemisia tabaci. Phytoparasitica.; 22: 189-196.

[21] Asghar Mohammadbeigi and G. Port,2013. Efficacy of Beauveria bassiana and Metarhizium anisopliae against Uvarovistia zebra (Orthoptera: Tettigoniidae) via contact and ingestion ,Intl J Agri Crop Sci. Vol., 5 (2), 138-146.

[22] Zaki, H.N. 1998. Efficiency of the entomopathogenic fungus, Beauveria bassiana (Bals), against Aphis crassivora Koch and Bemesiatabaci, Gennadius. Journal of Applied Entomology 22: 397-399.

[23] NARC, 2011. Action research on technology generation for the management of whitefly, Bemisia tabaci (Gennadius). Annual Technical Report 2009-11. Entomology Division, Nepal Agricultural Research Council, Khumaltar, Lalitpur 29-30. 